\title{
Research on the Growth of TFP of the Urban Commercial Banks Based on the Malmquist productivity index
}

\author{
Wen Hongmei ${ }^{1}$, Sui $\mathrm{Xin}^{1, *}$ and $L u$ Shaopeng ${ }^{1}$ \\ ${ }^{1}$ School of Finance, Harbin University of Commerce, Harbin150000, China
}

\begin{abstract}
This paper measures the total factor productivity (TFP) growth of 40 urban commercial banks based on the Malmquist productivity index. On this basis, the first - order difference GMM is used to estimate the influencing factors of the TFP of urban commercial banks. This paper show that the technological progress during the sample period has promoted the overall upward trend of the TFP of China's commercial banks. And the rate of return on assets has a significant positive impact on the TFP, and the deposit and loan ratio has a significant negative impact on TFP. At the same time, we have also concluded that the factors affecting the TFP of the three major regions in East, West and West are different.
\end{abstract}

\section{INTRODUCTION}

When the first urban commercial bank of China has been listed since 1995, our urban commercial bank has shown a good momentum of development. Especially in 2004, with the promulgation of the outline of regulation and development of the city commercial bank, the urban commercial bank has entered a stage rapid of development. According to the statistics from China banking regulatory commission, by the end of 2015 , the number of urban commercial bank institutional is 133 , the total of assets is 22.68 trillion, it has increased nearly 4 times than 4.7 trillion in 2004, the assets accounted share for $11.38 \%$ of the whole banking financial institutions, and $1.4 \%$ of the non-performing loan ratio has been a lower level compared with the same commercial Banks. However, with the deepening reform of financial in our country, the development of the urban commercial bank turning, asset grow, non-performing loans increased, profit space narrowing and monomer differentiation acceleration and other issues make it into the downlink channel. In this context, the traditional extensive expansion mode has no longer adapts to the current development need, and the improvement of the efficiency of the bank is the key to the sustainable development of the city commercial bank. This paper aims to measure the total factor productivity to judge its core competitive power of city firms, and through the analysis of the influence factors to find out the effective ways to promote the TFP of Banks, thus to provide the realistic guidance for the future development of urban commercial bank

\section{Literature Review}

The study of the efficiency of Banks can dates back to the 1950s, and the efficiency of Banks has been

* Corresponding author: 513119931@.qq.com

* International social science foundation(16BJL037) widely watched by scholars since then. The research on the efficiency of Banks in foreign countries has gone through three stages. The research focuses on the scale efficiency of the bank, the scope efficiency and the current frontier efficiency. The analysis of the dynamic efficiency of total factor productivity of Banks has become a hot topic in the current research. The method has been widely used in the research since the Malmquist production index method was constructed to calculate the total factor productivity in the study of foreign scholars Charnes and Coopor et al. (1978). In the case of emp irical analysis, the methods for TFP of Banks in Spain, the United States and Kuwait were quantitatively calculated based on this method, such as those of the bank of Spain, the United States, and the Kuwaiti bank of Kuwait. Park (2006) research on the Korean banking TFP found that a sharp rise in its technical progress index led to a general increase in TFP in the banking sector. Domestic scholar Zhang Jianhua (2003) first used the Malmquist index to quantify the total factor productivity index of China's banking industry, and found that the TFP of China's banking industry showed an upward trend. Wang Fubiao (2006) also confirmed this conclusion based on empirical research on the same method. Different from the above research results, Zhu Chao (2006) and Cai Yuezhou, Guo Meijun (2009), which is based on different data samples using the same Malmquist index method, it is concluded that the average values of TFP in China's banking industry is on the decline.

From the grasp of the paper, most scholars on the research methods using TFP Malmquist productivity index of the bank, in the aspect of the research object is the TFP of listed commercial Banks more, there is little study on city business TFP. In this paper, based on the above research, and considering the features of China's 
three biggest region's history, selected the features three regions of 40 city business of large sample of panel data from 2011 to 2015, based on Malmqiust productivity index of city business in China and quantitatively analysis and decomposition of total factor productivity. At the same time, the influence factors of TFP were studied by using the first order difference GMM to determine the effective ways to improve the efficiency of the city. Through the study of this paper, the author tries to supplement and perfect the related research on total factor productivity of our city, and provide some suggestions for the sustainable development of the city.

\section{Total Factor Productivity Measure and Decomposition of City Commercial Banks}

\section{1. index selection}

1. Sample selection and data source

In order to measures the total factor productivity of urban commercial banks, the paper selects 40 urban commercial banks as samples., we chose the period from 2011 to 2015 during the sample survey period, the requirements for information disclosure of city businesses were higher, so the data's desirability and integrity were better. This paper selects 18 urban commercial banks in the eastern region, 13 in the central region, 9 in west western region, main ly fro $m$ the annual reports of commercial banks, the annual report of the banking regulatory commission and related web data.

2. Selection of input and output indexes

Based on the production method and mediation method as the main basis of input and output index selection, choose the bank employees, total as sets, bank branches and deposits as input indicators, with pre-tax profits and total loans as output indicators, descriptive statistics related index data can be found in the table 1 .

Table 1 descriptive statistics of indicators selected

\begin{tabular}{|c|c|c|c|c|c|}
\hline & $\begin{array}{l}\mathrm{Mi} \\
\mathrm{n}\end{array}$ & Max & Mean & $\begin{array}{l}\text { Std.De } \\
\text { v. }\end{array}$ & $\begin{array}{l}\mathrm{Ti} \\
\mathrm{me}\end{array}$ \\
\hline Bank branch & 11 & 534 & 151 & $\begin{array}{l}103.38 \\
52\end{array}$ & $\begin{array}{l}20 \\
0\end{array}$ \\
\hline The bank employee & $\begin{array}{l}69 \\
4\end{array}$ & $\begin{array}{l}1404 \\
6\end{array}$ & 4189 & $\begin{array}{l}2733.2 \\
514\end{array}$ & $\begin{array}{l}20 \\
0\end{array}$ \\
\hline The total assets of & $\begin{array}{l}84 . \\
39 \\
\end{array}$ & $\begin{array}{l}1844 \\
9.09 \\
\end{array}$ & $\begin{array}{l}2595.5 \\
647 \\
\end{array}$ & $\begin{array}{l}2875.2 \\
668 \\
\end{array}$ & $\begin{array}{l}20 \\
0 \\
\end{array}$ \\
\hline $\begin{array}{l}\text { The total amount of } \\
\text { the deposit }\end{array}$ & $\begin{array}{l}29 . \\
71\end{array}$ & $\begin{array}{l}1022 \\
3.00 \\
\end{array}$ & $\begin{array}{l}1681.7 \\
286\end{array}$ & $\begin{array}{l}1721.1 \\
046\end{array}$ & $\begin{array}{l}20 \\
0 \\
\end{array}$ \\
\hline Pre-tax profits & $\begin{array}{l}0.3 \\
1 \\
\end{array}$ & $\begin{array}{l}210.8 \\
5 \\
\end{array}$ & $\begin{array}{l}33.494 \\
7 \\
\end{array}$ & $\begin{array}{l}34.034 \\
3 \\
\end{array}$ & $\begin{array}{l}20 \\
0 \\
\end{array}$ \\
\hline $\begin{array}{l}\text { The total amount of } \\
\text { the loan }\end{array}$ & $\begin{array}{l}11 . \\
54\end{array}$ & $\begin{array}{l}1336 \\
9.96 \\
\end{array}$ & $\begin{array}{l}1123.1 \\
693 \\
\end{array}$ & $\begin{array}{l}1487.3 \\
249 \\
\end{array}$ & $\begin{array}{l}20 \\
0 \\
\end{array}$ \\
\hline
\end{tabular}

3.2. analys is of the calculation results

Table 2 shows the total factor productivity and decomposition results of the sample city business lines from 2011 to 2015 . It can be concluded that, on the whole, the increase of technical level is greater than the technical efficiency, which leads to the growth of the TFP index of the sample cities in China. Second, from the point of time dimension, besides the TFP of value is less than 1 in 2014, the rest were greater than 1 year, so the city firm in the sample interval of TFP index showed up - down - the rising trend; Third, from the spatial dimension, the TFP of the three regions of eastern and western regions of the east and China are all showing an upward trend under the impetus of technological progress.

Table 2 TFP index and decomposition results obtained by time and region classification

\begin{tabular}{l|l|l|l|l|l|l}
\hline & $\begin{array}{l}\text { Simple } \\
\text { size }\end{array}$ & TFP & TECH & EFF & PE & SE \\
\hline simple & 200 & 1.036 & 1.091 & 0.949 & 0.976 & 0.973 \\
\hline time & & & & & & \\
\hline 2012 & 40 & 1.046 & 1.151 & 0.909 & 0.950 & 0.957 \\
\hline 2013 & 40 & 1.075 & 1.289 & 0.834 & 0.940 & 0.887 \\
\hline 2014 & 40 & 0.983 & 0.968 & 1.015 & 1.011 & 1.004 \\
\hline 2015 & 40 & 1.041 & 0.988 & 1.054 & 1.005 & 1.049 \\
\hline Area & & & & & & \\
\hline East & 72 & 1.044 & 1.108 & 0.978 & 0.981 & 0.973 \\
\hline Middle & 52 & 1.255 & 1.253 & 0.982 & 0.977 & 0.967 \\
\hline weat & 36 & 1.011 & 1.075 & 0.966 & 0.973 & 0.969 \\
\hline $\mathbf{4}$ Study
\end{tabular}

4 Study on the influence factors of TFP of urban commercial Banks

4.1. variable selection and model construction a. Selection of variables

The study on the influence factors of TFP on urban commercial banks is mainly to clarify the effective way to improve TFP of city businesses by examining and analyzing the significance of influencing factors. Table 3 lists the definitions of each variable and the descriptive statistics.

Table 3 variable definition tables

\begin{tabular}{c|c|c|c|c|c}
\hline Variable & mean & Mean & Std.Dev. & Min & Max \\
\hline ln_tasset & Bank size & 7.55 & 1.03 & 4.44 & 9.82 \\
\hline roa & profitability & 1.11 & 0.25 & 0.05 & 1.83 \\
\hline crar & Security level & 10.63 & 1.72 & 6.90 & 18.47 \\
\hline rld & Asset allocation & 0.85 & 0.99 & 0.05 & 6.51 \\
\hline npl & Level of risk & 1.00 & 0.59 & 0.00 & 5.59 \\
\hline district & Management ability & 0.51 & 0.92 & 0.00 & 11.18 \\
\hline
\end{tabular}

4.1. Model construction

In order to measures the influence factors of total factor productivity (TFP) growth of 40 urban commercial banks, TFP value calculated above city firms here is as explained variable, select the above six variables as explanatory variables. In addition, to investigate whether the above variables can have an impact on the TFP decomposition of city businesses, it is also considered that TECH and EFF are considered as explanatory variables. This paper builds a dynamic panel model based on the relevant data of sample commercial bank. Even the jade king (2010), for sample shorter dynamic panel data, using GMM estimation can obtain consistent estimator, so this article USES the first order difference GMM estimation to calculate the model, the model set is as follows:

$$
y_{i t}=\gamma y_{i, t-1}+x_{i t}^{\prime} \beta+\alpha_{i}+\varepsilon_{i t}
$$


In this case, $y_{i t}$ is be explained variable, $\mathrm{I}$ is urban commercial banks, $\mathrm{i}=1,2, \ldots, 40, \mathrm{t}$ means time; $\gamma$ is coefficients of the first order delay $y_{i, t-1}$ of the explained variables; $\beta \mathrm{i}$ in the variable coefficient, $\beta=\left(\beta_{1}, \beta 2, \beta 3, \beta 4, \beta 5, \beta 6\right)^{\prime}$ interpreting xit means $x_{i t}=(\text { ln_tasset, roa, crar, rld }, \text { npl, district })^{\prime}$

random disturbance, $\varepsilon_{i t} \square$ i.i.d.N $\left(0, \sigma_{\varepsilon}^{2}\right)$.

B. analysis of empirical results

a. Overall panel data regression

Dynamic panel based on the established model of regression, the estimated results as shown in the table 4 , in view of this part mainly TFP is city firms and the influence factors of the decomposition of item analysis, so this list only a part of the measuring results. Table 4 reports three models that are explained separately with TFP, EFF, and TECH.

Table 4 TFP, TECH and EFF dynamic panel regression

\begin{tabular}{|c|c|c|c|c|c|c|c|c|c|}
\hline \multirow[t]{2}{*}{$\begin{array}{l}\text { explained } \\
\text { variable }\end{array}$} & \multicolumn{3}{|c|}{$\begin{array}{l}\text { Modell } \\
\text { Be exphained variable: TFP }\end{array}$} & \multicolumn{3}{|c|}{$\begin{array}{l}\text { Model II } \\
\text { Be explained variable: EFF }\end{array}$} & \multicolumn{3}{|c|}{$\begin{array}{l}\text { Model III } \\
\text { Be explained varible: TECH }\end{array}$} \\
\hline & Coefficicint & $\begin{array}{l}\text { Standard } \\
\text { error }\end{array}$ & $\mathrm{Z}$ value & coefficient & $\begin{array}{l}\text { Standard } \\
\text { eerror }\end{array}$ & $Z$ value & coeffxient & $\begin{array}{l}\text { Sandard } \\
\text { error } \\
\end{array}$ & $\mathrm{Z}$ value \\
\hline nn_ & -0.276 & 0.187 & -1.48 & 0.001 & 0.077 & 0.01 & $-0.328^{* *}$ & 0.154 & -2.13 \\
\hline roa & $1.094^{* *}$ & 0.477 & 2.29 & $0.453^{* *}$ & 0.192 & 2.35 & 0.053 & 0.352 & 0.15 \\
\hline crar & 0.022 & 0.079 & 0.28 & -0.039 & 0.030 & -1.29 & -0.004 & 0.060 & -0.07 \\
\hline rld & $-2.801 * *$ & 1.096 & -2.55 & -0.033 & 0.401 & -0.08 & -0.084 & 0.725 & -0.12 \\
\hline npl & 0.187 & 0.212 & 0.88 & $0.211^{* *}$ & 0.087 & 2.44 & $-0.284 * *$ & 0.155 & -1.83 \\
\hline district & 0.151 & 1.023 & 0.15 & 0.387 & 0.431 & 0.9 & -0.319 & 0.804 & -0.4 \\
\hline _cons & $4.757^{* * *}$ & 1.858 & 2.56 & 0.368 & 0.688 & 0.53 & $4.782^{* * * *}$ & 1.477 & 3.24 \\
\hline Wald chi2 & \multicolumn{3}{|l|}{16.92} & \multicolumn{3}{|l|}{15.37} & \multicolumn{3}{|l|}{14.33} \\
\hline Prob $>$ chi 2 & \multicolumn{3}{|l|}{0.0179} & \multicolumn{3}{|l|}{0.0316} & \multicolumn{3}{|l|}{0.0456} \\
\hline
\end{tabular}

According to the empirical results can get the following conclusions: (1) about the influence factors of total factor productivity (TFP) study: return on assets (roa) and LDR (RLD) has a significant influence on city business of TFP, and total assets (ln_tasset), core tier 1 capital ratio (crar), non-performing loans (NPL) and frag mentation coefficient (district) failed to pass the test of significance. In particular, the yield of assets has a positive influence on TFP index of our city business bank, and the deposit and loan ratio has negative influence on it. (2) research on the impact factors of technical efficiency change (EFF) : asset and nonperforming loan ratios have passed the significance test at a confidence level of 5\%. (3) research on the impact factors of technical level change (TECH) : asset size and non-performing loan ratio have significant negative effects on technical level.

b. East and west panel data regression

At this stage, the economic and financial environment of the three regions of China's east and west are very different, and this paper makes a return to the sample cities and businesses in different regions based on this thesis. The parameters of the three-region dynamic panel are shown in table 5 .

Table 5 regression results of TFP dynamic panel in eastern and western regions

\begin{tabular}{|c|c|c|c|c|c|c|}
\hline \multirow{2}{*}{$\begin{array}{l}\text { explained } \\
\text { variable }\end{array}$} & \multicolumn{2}{|l|}{ east } & \multicolumn{2}{|l|}{ middle } & \multicolumn{2}{|l|}{ west } \\
\hline & $\begin{array}{l}\text { coefficien } \\
\text { t value }\end{array}$ & $\begin{array}{l}\mathrm{Z} \\
\text { valu } \\
\mathrm{e} \\
\end{array}$ & $\begin{array}{l}\text { coefficien } \\
\text { t value }\end{array}$ & $\begin{array}{l}\mathrm{Z} \\
\text { valu } \\
\mathrm{e} \\
\end{array}$ & $\begin{array}{l}\text { coefficien } \\
t \text { value }\end{array}$ & $\begin{array}{l}\mathrm{Z} \\
\text { valu } \\
\mathrm{e}\end{array}$ \\
\hline ln_tasset & 0.1171 & 1.04 & -0.3810 & $\overline{0} .85$ & -0.0866 & $\overline{0} .80$ \\
\hline roa & $\begin{array}{l}0.7560 * * \\
*\end{array}$ & 5.70 & 1.3127 & 1.08 & $\begin{array}{l}0.9577 * * \\
*\end{array}$ & 2.91 \\
\hline crar & -0.0088 & - & 0.0278 & 0.15 & -0.0527 & - \\
\hline rld & $\begin{array}{l}0.9480 * * \\
*\end{array}$ & 2.74 & $-\overline{5.0553 * *}$ & - & 0.9484 & 1.13 \\
\hline $\mathrm{npl}$ & 0.0745 & 1.49 & 0.1178 & 0.12 & 0.0667 & 0.50 \\
\hline district & 0.1536 & 0.52 & -0.8882 & $\overline{0} .24$ & 0.1082 & 0.20 \\
\hline _cons & -0.7248 & $\overline{0}-68$ & 6.8355 & 1.54 & -0.1060 & $\overline{0} .13$ \\
\hline
\end{tabular}

Based on the estimated results, TFP in the eastern region is significantly affected by the ratio of asset yield and loan-to-deposit ratio. A mong them, the coefficient of the variable of the asset return is positive, and its symbol direction is consistent with the overall regression result, so it is no longer detailed. LDR coefficient is positive shows high deposit-loan ratio can help improve the TFP of city business value, the conclusion can be answered from the perspective of bank profitability, because higher LDR is usually relative to the deposit of the loan proportion is larger, it spreads as the main source of income of city business profits will increase and therefore, to play a positive role in driving the TFP of city business. Secondly, the TFP in the central region of the city only has a significant test of deposit and loan ratio, and the coefficient of loan-to-deposit ratio is negative, indicating that the increase of the loan-todeposit ratio is unfavorable to TFP of the city business. Finally, the coefficient of commercial bank in western regions is positive, which also indicates that the increase of asset yield has a positive effect on bank efficiency.

\section{Conclusion}

This paper measures the total factor productivity (TFP) growth of 40 urban commercial banks during 2011-2015 by the Malmquist productivity index. $\mathrm{n}$ this basis, the article first order difference GMM estimation for the influence factors of city business index of TFP and its decomposition has carried on the empirical research, the results showed that: (1) in the inspection period, 2011-2015 sample city firm's total factor productivity under the role of technological progress is on the rise as a whole. In terms of time dimension, except for the decline of TFP in the city in 2014, the other years showed a good upward trend. From the spatial dimension, TFP of the city in the central region is the fastest growing, the second in the east and the slowest in the west. (2) the return on assets to the firm's total factor productivity and technical efficiency has a significant positive effect, asset size has a significant negative influence on technical level, the significant 
negative impact on the deposit-loan ratio on total factor productivity non-performing loan ratio has a significant positive influence on technical efficiency, and has a significant negative influence on technical level. (3) return on assets and the deposit-loan ratio and total factor productivity to east city firm was significantly positively related to relationship between the LDR with central city business was significantly positively related to relationship between total factor productivity, return on assets and businesses in the western region city was significantly positively related to relationship between total factor productivity.

\section{References}

1. Charnes A, Cooper W W, Rhodes E. Measuring Efficiency of Decision Making Units[J]. European Journal of Operational Research, 1978 (3) : 429-444.

2. E.Grifell-Tatje, Lovell C.A.K. The Sources of Productivity Change in Spanish Banking[J]. European Journal of Operational Research , 1997 (5) : 364-380.

3. David C. Wheelock, Paul W. Wilson. Technical Progress, Inefficiency, and Productivity Change in US Banking, 19841993. Journal of Money, Credit, and Banking, 1999, 31 (2) : 212-234.

4. Darra A F C, Topuz T, Yousef. Assessing Cost and Technical Efficiency of Banks in Kuwait. Working Paper, 2002

5. Park K H, Weber L.A. Note on Efficiency and Productivity Growth in the Korean Banking Industry, 1992-2002. Journal of Banking and Finance, 2006, 30 (12) : 2371-2386.

6. Chung, Y., R. Fare and S. Grosskopf. Productivity and Undesirable Outputs : A Directional Distance Function Approach[J]. Journal of Environment Management , 1997 (51) $229-240$.

7. Fujji, H., S. Managi and R. Matousek. Indian Bank Efficiency and Productivity Changes with Undesirable Outputs : A DisaggregatedApproach[J]. Journal of Banking \& Finance, 2014 (38) , 41-50.

8. Caves D, Christensen L, Diewert W. The Econonic Theory of Index Numbers and Measurement of Input , Output and Productiviy[J]. Journal of Econometrics , 1982 (6) : 1393-1414. 